\title{
Menakar Fungsi Izin Dan Mediasi Pada Sengketa Perceraian Di Kalangan Pegawai Negeri Sipil Kota Mataram Dari Tahun 2010-2020
}

\author{
Muhammad Idrus \\ Lembaga Penjamin Mutu Pendidikan Provinsi NTB
}

\begin{abstract}
Abstrak
Perceraian merupakan salah satu peristiwa dalam suatu perkawinan yang secara agama dimungkinkan untuk terjadi. Bagi umat islam perkara perceraian merupakan hal yang halal namun dibenci oleh "Allah SWT". Bagi Pegawai Negeri Sipil (PNS) Perceraian dapat dilakukan dengan mekanisme yang telah diatur dalam Undang-Undang. Salah satunya adalah Izin yang diperoleh dan tahapan Mediasi yang harus dilakukan, namun pada prakteknya masih banyak kendala-kendala teknis terkait penyelenggaraan izin perceraian bagi PNS, hal ini tentunya menjadi pehatian bagi banyak pihak. Penelitian ini kemudian mengkaji fungsi izin dan mediasi pada sengketa perceraian di kalangan pegawi negeri sipil, meskipun tujuan dari diperlukan Izin perceraian sesungguhnya dalah dalam rangka mempersulit (mencegah) terjadinya perceraian di lingkup Pegawai Negeri Sipil, Penelitian ini mengkaji Izin perceraian dan Tahapan Mediasi bagi Pegawai Negeri Sipil yang ingn bercerai di Kota Mataram dari tahun 2010-2020. Dengan menggunakan metode kualitatif dengan dipadukan dengan kajian normatif.
\end{abstract}

Kata Kunci : Izin Perceraian, Mediasi Perceraian, PNS Kota Mataram

Abstract

Divorce is one of the events in a marriage that is religiously possible. For Muslims the case of divorce is halal but hated by "Allah SWT". For Civil Servants (PNS) Divorce can be done by the mechanism that has been regulated in the Law. One of them is the permit obtained and the stage of mediation that must be done, but in practice there are still many technical obstacles related to the implementation of divorce permits for civil servants, this is certainly a concern for many parties. This research then examines the function of permits and mediation in divorce disputes among civil servants, although the purpose of the required divorce permit is actually in order to complicate (prevent) the occurrence of divorce in the scope of civil servants, this study examines divorce permits and mediation stages for civil servants who are divorced in Mataram city from 2010-2020. By using qualitative methods combined with normative studies.

Keywords: Divorce Permit, Divorce Mediation, Mataram City Civil Servant

\section{A. Pendahuluan}

Di Indonesia sendiri secara historis sosiologis, perhatian terhadap nasib atau hakhak perempuan mulai diperhatikan sejak R.A. Kartini menjadi ikon emansipasi perempuan. Sejak itu pula perempuan mulai berperan serta aktif, baik di sektor 
pendidikan maupun sosial kemasyarakatan. Kartini tidak saja dikenal karena kegigihannya melawan penindasan terhadap kaumnya pada saat itu yang dianggap tak lazim, namun juga menyemangati kaum perempuan Indonesia untuk sadar terhadap eksistensi perempuan di tengah masyarakat, baik dalam skala kecil maupun skala yang lebih besar.

Keberadaan perundang-undangan yang mengakomodir kepentingan kaum hawa secara historis sudah dimulai sejak lama diharapkan dan dinantikan, bahkan sebelum kemerdekaan. Berawal dari konggres ikatan sarjana wanita (ISWI) sampai unjuk rasa di Gedung DPR pada awal tahun 1970 an. Rupanya, komitmen bersama kaum wanita Indonesia tak pernah berhenti. Beberapa kelompok kaum wanita Indonesia di awal abad ke-20an mulai menampakkan keinginannya, mulai dengan pembentukan lembaga sampai dengan mengkomunikasikan komitmen perjuangan wanita Indonesia lewat panggung politik parlemen. Hal tersebut dianggap pemerintah cukup serius, walaupun beberapa kalangan agamawan menentangnya dengan alasan bukan prioritas.

Pada Tahun 1974, akhirnya perjuangan kaum wanita untuk mendapatkan payung hukum terhadap hak-haknya terbukti sudah dengan lahirnya UndangUndang Nomor 1 Tahun 1974 tentang Perkawinan. Undang-Undang ini banyak melindungi perempuan dari tindakan sewenang- wenang dari oknum laki-laki sehingga diharapkan bahwa pada saat selanjutnya akan memberikan efek jera dan sekaligus sikap hati-hati para lelaki. Satu tahun kemudian, terbitlah Peraturan Pemerintah Nomor 9 tahun 1975 tentang pelaksanaan Undang-Undang Nomor 1 Tahun 1974 tentang Perkawinan. Namun demikian, meski telah dikeluarkan aturan perundang-undangan pelecahan terhadap kaum perempuan masih terjadi.

Pada tahun 1983 atau 9 (Sembilan) tahun sejak keluarnya Undang-Undang Nomor 1 Tahun 1974, terbitlah Peraturan Pemerintah Nomor 10 tahun 1983 tentang Izin Perkawinan dan Perceraian bagi Pegawai Negeri Sipil dan kemudian disempurnakan 7 tahun kemudian oleh Peraturan Pemerintah Nomor 45 Tahun 1990 tentang Perubahan atas Peraturan Pemerintah 10 Tahun 1983 tentang Izin Perkawinan dan Perceraian bagi Pegawai Negeri Sipil. Rupanya, pemerintah sebagai pelaksana roda pemerintahan ingin memberikan bukti nyata kepada masyarakat. Ini 
simbol baik karena pemerintah yang paling bertanggungjawab dalam memberi teladan pelaksanaan peraturan perundang-undangan, terutama di kalangan Pegawai Negeri Sipil.

Pegawai Negeri Sipil sebagai unsur aparatur negara, dan abdi masyarakat yang profesional diharapkan dapat menjadi teladan yang baik bagi masyarakat dalam tingkah laku, tindakan dan ketaatan kepada peraturan perundang-undangan yang berlaku. Indonesia sebagai negara hukum, artinya setiap tindakan yang dilakukan negara (pemerintah) dan warga negara harus didasarkan pada peraturan perundangan yang berlaku, sehingga tidak dibenarkan bertindak atas kehendak sendiri atau di luar hukum. Sebagai unsur aparatur negara yang profesional dan bermartabat, Pegawai Negeri Sipil dalam melaksanakan tugasnya diharapkan tidak terganggu oleh urusan kehidupan rumah tangga/keluarganya.

Perkawinan merupakan sendi dasar pembentukan keluarga, masyarakat dan bangsa dalam suatu Negara. Pembentukan masyarakat dan bangsa dalam suatu Negara dimulai dari pembentukan keluarga. ${ }^{1}$ Perkawinan dimulai dari ikatan seorang laki-laki dan dengan seorang wanita yang menurut peraturan perundangundangan maupun agama dianggap telah memenuhi persyaratan, selanjutnya disebut suami istri. Sebagaimana dinyatakan dalam Kitab Suci Al-Qur'an Surat Annissa (1) yang artinya:

"Hai sekalian manusia, bertakwalah kepada Tuhan-mu yang telah menciptakan kamu dari seorang diri, dan dari padanya Allah menciptakan istrinya, dan dari pada keduanya Allah memperkembang biakkan laki-laki dan perempuan yang banyak. Dan bertakwalah kepada Allah yang dengan (mempergunakan) nama-Nya kamu saling meininta satu sama lain, dan (peliharalah) hubungan kerabat, sesungguhnya Allah selalu menjaga dan mengawasi kamu".2

Dalam pelaksanaannya di beberapa instansi pemerintah, beberapa ketentuan Peraturan Pemerintah Nomor 10 tahun 1983 tidak berjalan sebagaimana mestinya. Pegawai Negeri Sipil tertentu yang seharusnya tunduk patuh pada ketentuan Peraturan Pemerintah Nomor 10 tahun 1983 dapat menghindar, baik secara sengaja

${ }^{1}$ Abdurrahman Saleh and Ridwan Sahrani, Masalah Hukum Islam Di Indonesia (Bandung: Alumni, 1978).

${ }^{2}$ Departemen Agama RI, Al-Qur'an Dan Terjemahan (Jakarta: Pustaka Amani, 2006). 
maupun tidak, terhadap ketentuan tersebut. Beberapa perubahan dimaksud adalah mengenai kejelasan tentang keharusan mengajukan perimintaan izin dalam hal perceraian, larangan bagi Pegawai Negeri Sipil wanita untuk menjadi istri kedua/ketiga/keempat, pembagian gaji sebagai akibat terjadinya perceraian yang diharapkan lebih menjamin keadilan bagi kedua belah pihak.

Pasal 3 Peraturan Pemerintah Nomor 45 Tahun 1990 Tentang Perubahan Atas Peraturan Pemerintah Nomor 10 Tahun 1983 Tentang Izin Perkawinan dan Perceraian Bagi Pegawai Negeri Sipil, menyatakan :

1. Pegawai Negeri Sipil yang akan melakukan perceraian wajib memperoleh izin atau surat keterangan lebih dulu dari atasan;

2. Bagi Pegawai Negeri Sipil yang berkedudukan sebagai penggugat atau Pegawai Negeri Sipil yang berkedudukan sebagai tergugat untuk memperoleh izin atau surat keterangan harus mengajukan perimintaan secara tertulis;

3. Dalam surat perimintaan izin atau pemberitahuan adanya gugatan perceraian untuk mendapat surat keterangan, harus dicantumkan alasan yang lengkap yang mendasarinya.

Setiap atasan yang menerima perimintaan izin dari Pegawai Negeri Sipil dalam lingkungannya, baik untuk melakukan perceraian, atau untuk beristri lebih dari seorang, wajib memberikan pertimbangan dan meneruskan kepada pejabat di atasnya, melalui saluran hirarkhi dalam jangka waktu selambat-lambatnya 3 bulan terhitung mulai tanggal ia menerima perinintaan izin dimaksud. ${ }^{3}$

Hal yang paling ditekankan dalam penelitian ini adalah Pasal mengenai izin proses perceraian seorang Pegawai Negeri Sipil. Hal ini sangat penting menjadi studi penelitian karena hal inilah yang dianggap penulis rawan konflik sehingga wajarlah mendapatkan perhatian istimewa dalam rangkaian Pasal-Pasal tentang perkawinan dan perceraian Pegawai Negeri Sipil, sehingga harus melewati prosedur perizinan yang relatif ketat. Selain itu, sekali lagi perlu ditekankan seperti di atas bahwa karena Pegawai Negeri Sipil bagian dari pemerintah maka oleh karenanya,

\footnotetext{
${ }^{3}$ Sekretariat Bapek, Izin Perkawinan Dan Perceraian PNS, Peraturan Kepegawaian Yang Berkaitan Dengan Banding Adininistrtratif Ke BAPEK, 2007.
} 
mereka lah seharusnya contoh warga negara taat hukum, taat aturan atau dengan kata lain taat prosedur perizinan perkawinan.

Di samping itu, aturan perizinan dalam perceraian sepertinya dalam referensi hukum Islam klasik tak dikenal sama sekali. Perizinan dalam perceraian baru dikenal dalam Peraturan Pemerintah 10 tahun 1983 Tentang Izin Perkawinan bagi Pegawai Negeri Sipil dan Peraturan Pemerintah 45 tahun 1990 Tentang Perubahan atas PP 10 tahun 1983 tentang Izin Perkawinan bagi Pegawai Negeri Sipil. Perizinan yang dimaksud dalam perceraian menurut peraturan tersebut adalah baik dilakukan atas inisiatif suami (cerai talak) maupun oleh isteri (cerai gugat).

Dalam penelitian awal, penulis melihat terdapat hal-hal yang menarik, yaitu pertama, adanya sengketa perceraian di kalangan PNS cenderung mengabaikan izin tertulis atasan terlebih dahulu. Kedua, penulis menemukan bahwa selain izin atasan, fungsi mediasi dalam sengketa perceraian dipandang hanya unsur adiministratif saja sehingga cenderung diabaikan dan tidak termasuk dari bagian penting/keharusan yang dapat membatalkan perceraian.

Oleh karena itu, di sinilah kekhususan yang sungguh menarik untuk dijadikan rumusan masalah dalam penelitian ini yaitu tentang perizinan dan fungsi mediasi. Sungguh sangat menarik ketika penyusun melihat betapa pemerintah ingin menjaga moral para aparatur negara dengan mengaturnya dalam peraturan perundangundangan. Tindakan hukum dengan mencantumkan setiap Pegawai Negeri Sipil melewati prosedur perizinan perceraian maupun melakukan perkawinan selanjutnya (poligami) menjadi dilematis di kalangan PNS karena hal itu di samping merupakan tindakan preventif adiministratif sekaligus dianggap melebihi hukum perkawinan Islam klasik.

Beberapa kasus perizinan perceraian Pegawai Negeri Sipil diwarnai dengan sengketa antara pihak isteri dengan suami. Di lain pihak juga terjadinya karena sikap penghindaran mereka dari aspek publisitas, kurangnya kesadaran dan penguatan aspek hukum perkawinan, maupun intervensi pihak keluarga dalam perceraian maupun dalam hal penyelesaiannya. ${ }^{4}$

${ }^{4}$ Muhammad Idrus, "Arbitrase Perkawinan Di Indonesia Dan Pakistan (Sebuah Studi Komparatif)” (IAIN Sunan Kalijaga, 2003). 
Dalam kaitan dengan motivasi di atas, maka izin atasan lebih merupakan instrumen pencegahan, atau berkarakter sebagai preventif instrumental. ${ }^{5}$ Perizinan merupakan sarana pengendali terhadap kehidupan masyarakat, agar tidak menyimpang dari ketentuan peraturan perundang-undangan yang ada, dengan demikian juga dimaksudkan untuk membatasi aktivitas warga masyarakat, agar tidak merugikan hak orang lain.

Fungsi ketetapan dalam arti izin adalah berfungsi melaksanakan suatu undangundang, karena dengan demikian disebut peraturan organik, baik untuk UndangUndang maupun peraturan yang sifatnya masih abstrak. Artinya peraturan masih berlaku umum, masih mengikat secara umum, mengatur hal-hal yang umum. ${ }^{6}$

Dalam Kompilasi Hukum Islam halaman 17 Pasal 2 dinyatakan Perkawinan menurut hukum Islam adalah pernikahan, yaitu akad yang sangat kuat atau miitsaaqon gholiidhan untuk mentaati perintah Allah dan melaksanakannya merupakan ibadah. ${ }^{7}$ Oleh karena itu sangat dilarang jika perkawinan kedua sampai dengan keempat dilakukan hanya berdasarkan hawa nafsu belaka, oleh karena itu Islam sangat ketat memberikan persyaratan bagi umatnya untuk melakukan perkawinan lebih-lebih terhadap perkawinan yang kedua sampai keempat (poligami).

Untuk menegakan peraturan disiplin Pegawai Negeri Sipil dalam membina rumah tangga agar sesuai dengan yang diatur dalam Peraturan Pemerintah Nomor 45 Tahun 1990 tentang perubahan atas Peraturan Pemerintah Nomor 10 Tahun 1983, diharapkan Pegawai Negeri Sipil dapat memberikan contoh yang baik kepada masyarakat. Masyarakat yang berperadaban, bermoral, loyal dan patuh terhadap hukum positif dan ketentuan-ketentuan lainnya. ${ }^{8}$

Pelanggaran terhadap ketentuan hukum tersebut dapat dikenakan sanksi hukuman disiplin berdasarkan Peraturan Pemerintah Nomor 53 Tahun 2010 tentang Disiplin Pegawai Negeri Sipil. Semua macam sanksi hukuman disiplin itu

\footnotetext{
5 Philipus M. Hadjon, Pengantar Hukum Perizinan (Surabaya: Yuridika, 1993).

6 Bachsan Mustafa, Pokok-Pokok Hukum Adininistrasi Negara (Bandung: Alumni, 1985).

7 Direktorat Jenderal Pembinaan Kelembagaan Agama Islam Direktorat Pembinaan Badan Peradilan Agama, Kompilasi Hukum Islam, n.d.

${ }^{8}$ Miftah Toha, Birokrasi Dan Politik Di Indonesia (Jakarta: PT. Raja Grafindo Persada, 2002).
} 
dikeluarkan dengan suatu keputusan Pengadilan Tata Usaha Negara yang dapat digugat juga di Pengadilan Tata Usaha Negara. ${ }^{9}$ Sanksi administrasi diterapkan oleh pejabat tata usaha negara tanpa harus melalui prosedur peradilan. ${ }^{10}$ Bahwa Pengadilan Tata Usaha Negara merupakan suatu Badan Peradilan yang berdiri sendiri yang khusus menyelesaikan sengketa ketatausahaan Negara. ${ }^{11}$

Dari uraian di atas telah jelas bahwa kedudukan Pegawai Negeri Sipil, dimana kedudukan mereka dalam beberapa hal berbeda dengan warga negara biasa, karena kepadanya dipercayakan tugas menjalankan fungsi umum pemerintahan dan pembangunan. Mereka harus melayani masyarakat bukan dilayani dan mereka yang pertama harus mentaati peraturan perundang-undangan. Padahal, kepastian hukum dan ketertiban umum selalu menuntut agar ketentuan - ketentuan hukum tertulis ditaati. ${ }^{12}$

Oleh sebab itu Peraturan Pemerintah Republik Indonesia Nomor 45 Tahun 1990 tentang Izin Perkawinan dan Perceraian bagi Pegawai Negeri Sipil, harus dijadikan sebagai pedoman dalam membina dan membangun rumah tangga yang baik, rukun, damai, dan sejahtera sesuai yang diharapkan oleh seluruh masyarakat Indonesia. Sebagai sarana kontrol sosial maka hukum bertugas untuk menjaga agar masyarakat tetap dapat berada di dalam pola-pola tingkah laku yang telah diterima olehnya. ${ }^{13}$

Dari uraian di atas, dapatlah diskursus dalam penelitian ini adalah Bagaimana fungsi izin dan mediasi pada sengketa perceraian Pegawai Negeri Sipil di kota Mataram dalam kurun waktu tahun 2010-2020? Kenapa PNS di Kota Mataram dalam kurun waktu 2010 sd. 2020 cenderung melakukan perceraian dengan kurangnya pertimbangan terhadap izin atasan terlebih dahulu?

\footnotetext{
${ }^{9}$ Indroharto, Usaha Memahami Undang-Undang Tetang TUN (Jakarta: Pustaka Sinar Harapan, 2000).

10 Philipus M. Hadjon, Pengantar Hukum Administrasi Indonesia (Yogyakarta: Gadjah Mada University Press, 1990).

${ }^{11}$ Moch. Faisal Salam, Penyelesaian Sengketa PNS Di Indonesia Menurut Undang-Undang No. 43 Tahun 1999 (Bandung: Mandar Maju, 2003).

12 Soerjono Soekanto, Pokok-Pokok Sosiologi Hukum (Jakarta: PT. Raja Grafindo Persada, 1988).

13 Satjipto Raharjdo, Hukum Dan Masyarakat (Bandung: Angkasa, 1980).
} 
Penelitian merupakan suatu karya iliniah yang berkaitan dengan analisis yang dilakukan secara metodologis, sistematis dan konsisten. ${ }^{14}$ Oleh sebab itu penelitian ini adalah menggunakan penelitian hukum empirik yakni mengkaji hukum tidak sebagai norma yang otonom tetapi sebagai institusi sosial yang dikaitkan secara rill dengan variabel yang lain.

Penelitian ini menggunakan 4 (empat) model pendekatan, yakin pertama pendekatan hukum empirik (Socio-legal Approach), yakni pendekatan yang mengkaji hukum dalam realitasnya di lapangan, dalam hal ini mengenai aturanaturan yang berkenaan dengan ijin perceraian bagi Pegawai Negeri Sipil. kedua, pendekatan Konseptual (Conceptual Approach), yakni pendekatan yang mengkaji konsep-konsep perkawinan dan mekanisme pemberian izin perceraian bagi Pegawai Negeri Sipil. ketiga, pendekatan Hukum dan Perundang-Undangan (Statuta Approach), yakni pendekatan yang mengkaji peraturan perundang-undangan yang menjadi landasan dasar legalisasi pemberian ijin perceraian bagi Pegawai Negeri Sipil serta implementasinya. keempat, pendekatan kasus artinya pendekatan yang digunakan dengan mengkaji kasus yang terjadi, terkait implementasi PP No.45 tahun 1990 dan PP No.10 tahun 1983, kasus tersebut dihubungkan dengan peraturan perundang-undangan yang berlaku.

Sumber dan jenis data dalam penelitian ini berupa data primer dan data sekunder, data primer diperoleh dari responden yakni para Pegawai Negeri Sipil yang melakukan poligami dan perceraian berdasarkan berkas kepegawaian yang penulis dapatkan di instansi pemerintah. Penentuan sampel responden ditetapkan secara purposive sampling yakni ditentukan secara non random berdasarkan pertimbangan subyektif peneliti karena yang bersangkutan dianggap memahaini hal-hal yang ditanyakan. Cara ini menurut Soerjono Soekanto dimaksudkan agar unsur-unsur yang ditarik masuk ke dalam sampel yang ditarik. ${ }^{15}$ Sedangkan data sekunder diperoleh dari peraturan perundang-undangan, literatur dan atau pandangan para sarjana yang relevan dengan masalah yang dibahas.

14 Soerjono Soekanto, Pengantar Penelitian Hukum (Jakarta: UI Press, 1985).

15 Ibid. 
Teknik pengumpulan data bagi data primer dikumpulkan dengan teknik wawancara (interview) secara terstruktur dan mendalam (indepth interview) dengan para responden dengan alat bantu panduan pertanyaan. Sedangkan untuk data sekunder dikumpulkan dengan teknik studi dokumentasi mulai dari kegiatan menghimpun sampai dengan mengkaji data tersebut. Dan Teknik analisis data dilakukan dengan cara Data yang terkumpul selanjutnya dilakukan editing dan klasifikasi data kemudian dianalisis secara diskriptif kualitatif dengan logika berpikir induksi yakni proses berawal dari proposisi-proposisi khusus (sebagai hasil pengamatan) dan berakhir pada suatu kesimpulan (pengetahuan baru) berupa asas umum. Dalam prosedur induktif setiap proposisi itu hanya boleh dianggap benar kalau proposisi itu diperoleh sebagai hasil penarikan kesimpulan dari proposisiproposisi yang berkebenaran empiris.

\section{B. Konsep Perkawinan}

Perkawinan menurut arti aslinya adalah hubungan seksual, tetapi menurut arti majazi (metaporik) atau arti hukum yang dikemukakan oleh Hanafi menyatakan bahwa "perkawinan adalah akad (perjanjian) yang menjadikan halal hubungan seksual sebagai suami istri antara seorang pria dan seorang wanita". ${ }^{16}$

Sedangkan Perkawinan menurut hukum Islam adalah nikah, yaitu melakukan akad (perjanjian) suci untuk mengikat diri antara seorang laki-laki dan seorang perempuan untuk menghalalkan hubungan hukum antara kedua belah pihak untuk mewujudkan suatu kebahagiaan hidup keluarga yang diliputi rasa kasih sayang dan ketentraman dengan syatat-syarat yang diridhoi oleh Allah SWT.

Menurut Kompilasi Hukum Islam Perkawinan adalah akad yang sangat kuat atau initsaaqon gholiidhan untuk mentaati perintah Allah dan melaksanakannya merupakan ibadah. Dan perkawinan bertujuan untuk mewujudkan kehidupan rumah tangga yang sakinah, mawaddah dan rahmah. ${ }^{17}$ Sedangkan menurut Undang-undang Nomor 1 Tahun 1974 Pasal 1 menyatakan bahwa "Perkawinan

16 Ramulyo Idris, Hukum Perkawinan Islam Suatu Analisis Dari Undang-Undang Nomor 1 Tahun 1974 Dan Kompilasi Hukum Islam (Jakarta: Bumi Aksara, 2005).

17 Ibid. 
adalah ikatan lahir bathin antara seorang pria dengan seorang wanita sebagai suami isteri dengan tujuan membentuk keluarga (rumah tangga) yang bahagia dan kekal berdasarkan Ketuhanan Yang Maha Esa."

Sedangkan perceraian dalam istilah fiqih disebut dengan "thalaq" atau "furqah" yang berarti membuka ikatan atau membatalkan perjanjian. Yang dimaksud dengan "perceraian dalam hal ini adalah melepaskan ikatan perkawinan". ${ }^{18}$

Sedangkan menurut Kompilasi Hukum Islam, "putusnya perkawinan yang disebabkan karena perceraian dapat terjadi karena talak atau berdasarkan gugatan perceraian". Sedangkan Pasal 117 menyatakan bahwa: “Thalak adalah ikrar suami di hadapan sidang Pengadilan Agama yang menjadi salah satu sebab putusnya perkawinan dengan cara sebagaimana dimaksud dalam Pasal 129,130 dan 131".

Undang-Undang Nomor 1 Tahun 1974, Pasal 39 ayat 1, menyatakan bahwa "perceraian hanya dapat dilakukan di depan sidang pengadilan setelah pengadilan yang bersangkutan berusaha dan tidak berhasil mendamaikan kedua belah pihak" dan "untuk melaksanakan pereceraian harus ada cukup alasan bahwa antara suami isteri itu tidak dapat hidup rukun lagi sebagai suami isteri “.

Peraturan Pemerintah Nomor 10 Tahun 1983 memberikan ketentuan tentang perceraian yang akan dilakukan oleh Pegawai Negeri Sipil sebagai berikut :

1. Pegawai Negeri Sipil yang akan melakukan perceraian wajib memperoleh izin lebih dahulu dari pejabat ( Pasal 3 ayat 1 );

2. Perinintaan untuk memperoleh izin sebagaimana dimaksud dalam ayat 1 diajukan secara tertulis ( Pasal 3 ayat 2);

3. Dalam surat perinintaan izin perceraian harus dicantumkan alasan yang lengkap yang mendasar perinintaan izin perceraian itu (Pasal 3 ayat 3).

Sedangkan perceraian menurut Peraturan Pemerintah Nomor 45 Tahun 1990 berbunyi :

1. Pegawai Negeri Sipil yang akan mengajukan perceraian wajib memperoleh izin atau surat keterangan lebih dahulu dari pejabat (Pasal 3 ayat 1).

\footnotetext{
18 Rasyid Sulaeman, Fiqih Islam (Bandung: Sinar Baru Algesindo, 2003).
} 
2. Bagi Pegawai Negeri Sipil yang berkedudukan sebagai tergugat untuk memperoleh izin atau surat keterangan sebagaimana dimaksud dalam ayat 1 harus mengajukan peinintaan tertulis (Pasal 3 ayat 2).

3. Dalam perinintaan izin atau pemberitahuan adanya gugatan perceraian untuk mendapatkan surat keterangan harus dicantumkan alasan yang lengkap yang mendasarinya.

Implementasi menyangkut tentang pelaksanaan hukum di lapangan (law in action), artinya hukum tidak hanya dilihat pada tataran law in book (hukum yang ada dalam kitab hukum). Implementasi juga berarti mengukur tingkat efektivitas hukum, yaitu apakah hukum yang berupa norma dapat diterima masyarakat atau sebaliknya tidak diterima masyarakat, sekaligus mengukur juga tingkat pemahaman aparat penegak hukum terhadap aturan tadi. Implementasi menurut Van Meter dan Van Horn di dalam Abdul Wahab adalah "Sebagai tindakan yang dilakukan, baik individu-individu, pejabat, kelompok pemerintah atau swasta yang mengarah pada tercapainya tujuan yang digariskan dalam keputusan kebijakan". ${ }^{19}$ Implementasi atau pelaksanaan dari hukum merupakan bagian yang tidak terpisahkan dari kerangka efektivitas hukum, efektivitas hukum dalam hal ini tidak semata-mata tertuju kepada pelaksanaan hukum, tetapi bagaimana pelaksanaan hukum tadi dapat memberikan keadilan, kepastian dan kemanfaatan.

Di dalam tataran implementasi berhasil tidaknya hukum tersebut di masyarakat sangatlah tergantung dari tiga hal yaitu substansi, struktur, dan kultur masyarakat, tanpa ketiga hal tersebut mustahil penegakan hukum berjalan dengan baik. Hukum itu dilihat dari segi substansi atau materi harus memuat norma-norma (norm) yang jelas dan tidak kabur serta tidak meiniliki makna yang banyak, sehingga mudah ditafsirkan oleh orang lain secara tidak benar. Seperti halnya peraturan perundangundangan (hukum positif) dapat dilihat sebagai suatu aktivitas yang bersifat yuridis formal, artinya hukum dianggap sebagai representasi kehendak normatif masyarakat yang berupa prosedur-prosedur yang telah ditentukan. ${ }^{20}$

${ }_{19}$ Abdul Wahab, Analisis Kebijakan Dari Formulasi Ke Implementasi Kebijakan Negara (Jakarta: Bumi Aksara, 1997).

${ }^{20}$ Raharjdo, Hukum Dan Masyarakat. 
Demikian juga dengan fungsi peradilan sebagai tempat terakhir para pihak yang bertikai mencari keadilan, diharapkan dapat secara optimal menjalankan fungsinya deini menemukan sisi positif dari pertikaian, baik bagi penggugat atau tergugat. Walaupun deinikian, peradilan bukanlah sarana yang paling tepat untuk memulihkan hubungan perkawinan.

Lemahnya daya fungsi institusi mediasi dan rekonsiliasi (arbitrasi ) perkawinan misalnya sebelum peradilan, seringkali membawa lemahnya efektivitas dan efisiensi proses pra peradilan sehingga dapat menimbulkan rendahnya kepercayaan masyarakat pencari keadilan terhadap harkat dan martabat peradilan itu sendiri. ${ }^{21}$

Dalam hal ini, asas-asas perkawinan yang pada prinsipnya mempersulit terjadinya perceraian dan mengawasi poligami yang terdapat serangkaian perundang-undangan, bertujuan sebagi kontrol masyarakat terhadap praktek perkawinan, sekaligus juga sebagi alat rekayasa masyarakat untuk menciptakan dan mewujudkan kesejahteraan dan keutuhan keluarga lewat peraturan perundangundangan perkawinan. Sebagai suatu konsep hukum publik, wewenang terdiri atas sekurang-kurangnya tiga komponen, yaitu, "pengaruh, dasar hukum dan konformitas hukum". 22 Hukum dan konformitas hukum" harus ditunjuk dasar hukumnya, komponen konformitas hukum mengandung pengertian adanya standar wewenang, yakni standar hukum (untuk semua jenis) dan standar khusus (untuk semua jenis wewenang tertentu).

C. Mekanisme Izin dan Mediasi Perceraian Bagi Pegawai Negeri Sipil di Kota Mataram

Mekanisme Izin Perceraian bagi Pegawai Negeri Sipil diatur dalam Peraturan Pemerintah Pemerintah Nomor 45 Tahun 1990 dan Peraturan Nomor 10 Tahun 1983 tentang Izin Perkawinan dan Perceraian bagi Pegawai Negeri Sipil dalam Pasal 3 menyatakan :

${ }^{21}$ Wila Chandra Supriadi, , Hukum Perkawinan Indonesia Dan Belanda : Suatu Penelitian Sejarah Hukum Perbandingan Tentang Hukum Perkawinan Indonesia Dan Belanda Dalam Periode Tahun 1945 Sampai Sekarang (Bandung: Mandar Maju, 2002).

22 Philipus M. Hadjon, Penataran Hukum Administrasi (Surabaya, 1988). 
1. Pegawai Negeri Sipil yang akan melakukan perceraian wajib memperoleh izin atau surat keterangan lebih dahulu dari pejabat;

2. Bagi Pegawai Negeri Sipil yang berkedudukan sebagai Penggugat atau bagi Pegawai Negeri Sipil yang berkedudukan sebagai Tergugat untuk memperoleh izin atau surat keterangan sebagaimana dimaksud dalam ayat (1) harus mengajukan perinintaan secara tertulis;

3. Dalam surat perinintaan izin atau pemberitahuan adanya gugatan perceraian untuk mendapatkan surat keterangan harus mencantumkan alasan yang lengkap yang mendasarinya.

Kemudian, Undang-Undang Nomor 1 Tahun 1974 tentang perkawinan Pasal 39 menyatakan :

1. "Perceraian hanya dapat dilakukan di depan Sidang Pengadilan setelah Pengadilan yang bersangkutan berusaha dan tidak berhasil mendamaikan kedua belah pihak";

2. "Untuk melakukan perceraian harus ada cukup alasan, bahwa antara suami istri itu tidak akan hidup rukun sebagai suami istri";

3. "Tata cara perceraian di depan sidang Pengadilan diatur dalam peraturan perundangan tersendiri".

\section{Kemudian Pasal 40}

1. "Gugatan perceraian diajukan kepada Pengadilan";

2. "Tata cara mengajukan gugatan tersebut pada ayat (1) Pasal ini diatur dalam peraturan perundangan tersendiri".

Sejalan dengan perkara gugatan, maka pihak Pengadilan dapat mengambil tindakan preventif dengan mewajibkan pemenuhan nafkah oleh bekas suami kepada bekas istrinya, sesuai dengan Pasal 41 huruf c Undang-Undang Nomor 1 Tahun 1974 Tentang Perkawinan. Kemudian sementara berlangsungnya gugatan perceraian, Pengadilan juga dapat menentukan nafkah yang harus ditanggung oleh suami, menentukan hal-hal yang perlu untuk menjainin pemeliharaan barangbarang yang menjadi hak suami atau barang-barang yang menjadi inilik istri, sesuai 
dengan Pasal 24 ayat (2) Peraturan Pemerintah Nomor 9 tahun 1975 tentang Pelaksanaan Undang-Undang Nomor 1 Tahun 1974 tentang Perkawinan.

Khusus dalam perkara gugatan cerai karena alasan syiqaq (perselisihan yang tajam dan terus menerus antara suami dan istri), Undang-Undang Nomor 7 tahun 1989 Tentang Peradilan Agama mengaturnya dalam Pasal 76 menyatakan:

1. Apabila gugatan perceraian didasarkan atas alasan syiqaq, maka untuk mendapatkan putusan perceraian harus didengar keterangan-keterangan saksi-saksi yang berasal dari keluarga atau orang-orang yang dekat dengan suami istri;

2. Pengadilan setelah mendengar keterangan saksi tentang sifat persengketaan antara suami istri dapat mengangkat seorang atau lebih dari keluarga masing-masing pihak maupun orang lain untuk menjadi hakim, (juru damai wakil dari pihak suami/istri dalam proses perceraian).

Pasal 19 huruf f Peraturan Pemerintah Nomor 9 Tahun 1975:

Antara suami dan istri terus-menerus terjadi perselisihan dan pertengkaran dan tidak ada harapan akan hidup rukun lagi dalam rumah tangga. Kemudian, dalam Penjelasan Peraturan Pemerintah Nomor 9 Tahun 1975 tentang Pelaksanaan Undang-Undang Nomor 1 Tahun 1974 tentang Perkawinan Pasal 31 ayat (2) :

Usaha untuk mendamaikan suami istri yang sedang dalam pemeriksaan perkara gugatan untuk mengadakan perceraian tidak terbatas pada sidang pertama sebagaimana lazimnya dalam perkara perdata, melainkan pada setiap saat sepanjang perkara itu belum diputus oleh Hakim. Dalam mendamaikan kedua belah pihak, Pengadilan dapat meininta bantuan lain yang dianggap perlu.

Oleh karena itu, maka fungsi arbitrase Pengadilan Agama terdapat pada pencegahan perceraian sewenang-wenang, poligami yang tidak bertanggung jawab, upaya mendamaikan para pihak dalam gugatan perceraian karena alasan syiqaq, dan penentuan nafkah bagi bekas istri.

Pasal 5 ayat (2) menyatakan bahwa setiap atasan yang menerima perinintaan izin dari Pegawai Negeri Sipil dalam lingkungannya, baik untuk melakukan perceraian dan atau beristri lebih dari seorang, wajib memberikan pertimbangan dan meneruskan kepada Pejabat melalui saluran hirarki dalam 
jangka waktu selambat-lambatnya 3 (tiga) bulan terhitung mulai tanggal ia menerima perinintaan izin dimaksud.

Izin untuk bercerai dapat diberikan oleh Pejabat apabila:

1. Tidak bertentangan ajaran agama yang dianutnya;

2. Tidak bertentangan dengan peraturan perundang-undangan yang berlaku;

3. Alasan perceraian yang dikemukakan tidak bertentangan dengan akal sehat.

Izin untuk bercerai karena alasan istri mendapat cacat badan atau penyakit dengan akibat tidak dapat menjalankan kewajibannya sebagai istri, tidak diberikan oleh Pejabat. Selain itu izin cerai juga tidak diberikan apabila alasan perceraian tersebut terdapat hal-hal sebagai berikut:

1. Bertentangan dengan ajaran/peraturan agama yang dianut Pegawai Negeri Sipil yang bersangkutan;

2. Bertentangan dengan peraturan perundang-undangan yang berlaku; dan/atau

3. Alasan yang dikemukakan bertentangan dengan akal sehat.

Pasal 8 Peraturan Pemerintah Nomor 10 Tahun 1983 dan Peraturan Pemerinta Nomor 45 Tahun 1990 mengatur tentang akibat perceraian bagi Pegawai Negeri Sipil sebagai berikut:

1. Apabila perceraian terjadi atas kehendak Pegawai Negeri Sipil pria maka ia wajib menyerahkan sebagian gajinya untuk penghidupan bekas istri dan anak-anaknya;

2. Pembagian gaji sebagaimana dimaksud dalam ayat (1) ialah sepertiga untuk Pegawai Negeri Sipil yang bersangkutan, sepertiga untuk bekas istrinya, dan sepertiga untuk anak atau anak-anaknya;

3. Apabila dari perkawinan tersebut tidak ada anak maka bagian gaji yang wajib diserahkan oleh Pegawai Negeri Sipil pria kepada bekas istrinya ialah setengah dari gajinya;

4. Pembagian gaji kepada bekas istri tidak diberikan apabila alasan perceraian disebabkan karena istri berzinah, dan atau istri melakukan kekejaman atau 
penganiayaan berat baik lahir maupun bathin terhadap suami, dan atau istri telah meninggalkan suami selama dua tahun berturut-turut tanpa izin suami dan tanpa alasan yang sah atau karena hal lain diluar kemampuannya;

5. Apabila perceraian terjadi atas kehendak istri, maka ia tidak berhak atas bagian penghsilan dari bekas suaminya;

6. Ketentuan sebagaimana dimaksud dalam ayat (5) tidak berlaku, apabila istri meininta cerai karena dimadu, dan atau suami berzina, dan atau suami melakukan kekejaman atau penganiayaan berat baik lahir maupun batin terhadap istri, dan atau suami menjadi pemabuk, pemadat, dan penjudi yang sukar disembuhkan dan atau suami telah meninggalkan istri selama dua tahun berturut - turut tanpa izin istri dan tanpa alasan yang sah atau karena hal lain diluar kemampuannya;

7. Apabila bekas istri Pegawai Negeri Sipil yang bersangkutan kawin lagi, maka haknya atas bagian gaji dari bekas suaminya menjadi hapus terhitung mulai ia kawin lagi.

Khusus mengenai Sanksi bagi Pegawai Negeri Sipil yang tidak melalui izin terlebih dahulu ketika perceraian, telah diatur dalam Pasal 15 Peraturan Pemerintah Nomor 45 Tahun 1990 yang pada intinya menyatakan jika Pegawai Negeri Sipil tidak melaporkan perceraiannya dalam jangka waktu selambat-lambatnya satu bulan terhitung mulai terjadinya perceraian, maka ia dijatuhi salah satu hukuman disiplin berat yang diatur dalam Peraturan Pemerintah Nomorn 53 Tahun 2010 tentang Disiplin Pegawai Negeri Sipil.

Jika ditelusuri, hukuman disiplin berat yang diatur dalam Peraturan Pemerintah Nomor 53 Tahun 2010 mencakup :

1. Penurunan pangkat pada pangkat yang setingkat lebih rendah untuk paling lama 3 (tiga) tahun;

2. Pemindahan dalam rangka penurunan jabatan setingkat lebih rendah;

3. Pembebasan dari jabatan;

4. Pemberhentian dengan hormat tidak atas perinintaan sendiri sebagai Pegawai Negeri Sipil; 
5. Pemberhentian tidak dengan hormat sebagai Pegawai Negeri Sipil.

Mekanisme izin Perceraian Pegawai Negeri Sipil sebagai berikut :

1. Dasar Hukum : surat permohonan dari yang bersangkutan ke unit kerja; surat keterangan dari kepala unit kerja; Berita Acara Pemeriksaan dari kepala unit kerja; Surat keterangan dari kepala desa; Surat pernyataan 1/3 gaji atau 1/2 (jika tidak punya anak); Fotokopi surat nikah; Fotokopi SK terakhir; Fotokopi KTP; Surat persetujuan suami/istri; Photo suami/istri 3 lembar.

Undang-Undang Nomor 1 Tahun 1974 tentang Perkawinan (Lembaran Negara Tahun 1974 Nomor 1, tambahan Lembaran Negara Nomor 3019); Peraturan Pemerintah Nomor 10 Tahun 1983 tentang Izin Perkawinan dan Perceraian Pegawai Negeri Sipil; Peraturan Pemerintah Nomor 45 Tahun 1990 tentang Perubahan atas Peraturan Pemerintah Nomor 10 Tahun 1983 tentang Izin Perkawinan dan Perceraian Pegawai Negeri Sipil.

2. Persyaratan : Surat permohonan dari yang bersangkutan ke unit kerja; surat keterangan dari kepala unit kerja; Berita Acara Pemeriksaan dari kepala unit kerja; Surat keterangan dari kepala desa; Surat pernyataan 1/3 gaji atau 1/2 (jika tidak punya anak); Fotokopi surat nikah; Fotokopi SK terakhir; Fotokopi KTP; Surat persetujuan suami/istri; Photo suami/istri 3 lembar.

3. Unit kerja menyampaikan dokumen kelengkapan izin perceraian; Melakukan pemeriksaan kelengkapan berkas izin perceraian; Membuat surat panggilan 1 s.d. III (suami/istri); Persiapkan blanko hasil wawancara pada saat panggilan; Meminta keterangan tambahan izin dari unit kerja, anak, orang tua atau desa, dan lain sebagainya jika diperlukan; Membuat surat pernyataan 1/3 gaji atau 1/2 gaji (jika tidak punya anak); Membuat surat izin/surat keterangan izin perceraian; Membut berita acara penyerahan Surat Izin Perceraian / Surat Keterangan izin perceraian; Mengirim tembusan ke unit kerja yang relevan.

4. Waktu penyelesaian, 1 sampai dengan 3 minggu.

5. Biaya ditanggung oleh yang bersangkutan. 
6. Produk berupa : Surat Keputusan Pemberian Izin Perceraian; Surat Keputusan Penolakan Izin Perceraian.

Flowchat Mekanisme Izin Perceraian Pegawai Negeri Sipil sesuai dengan Peraturan Pemerintah Nomor 45 tahun 1990 dan Peraturan Pemerintah Nomor 10 Tahun 1983 sebagai berikut :

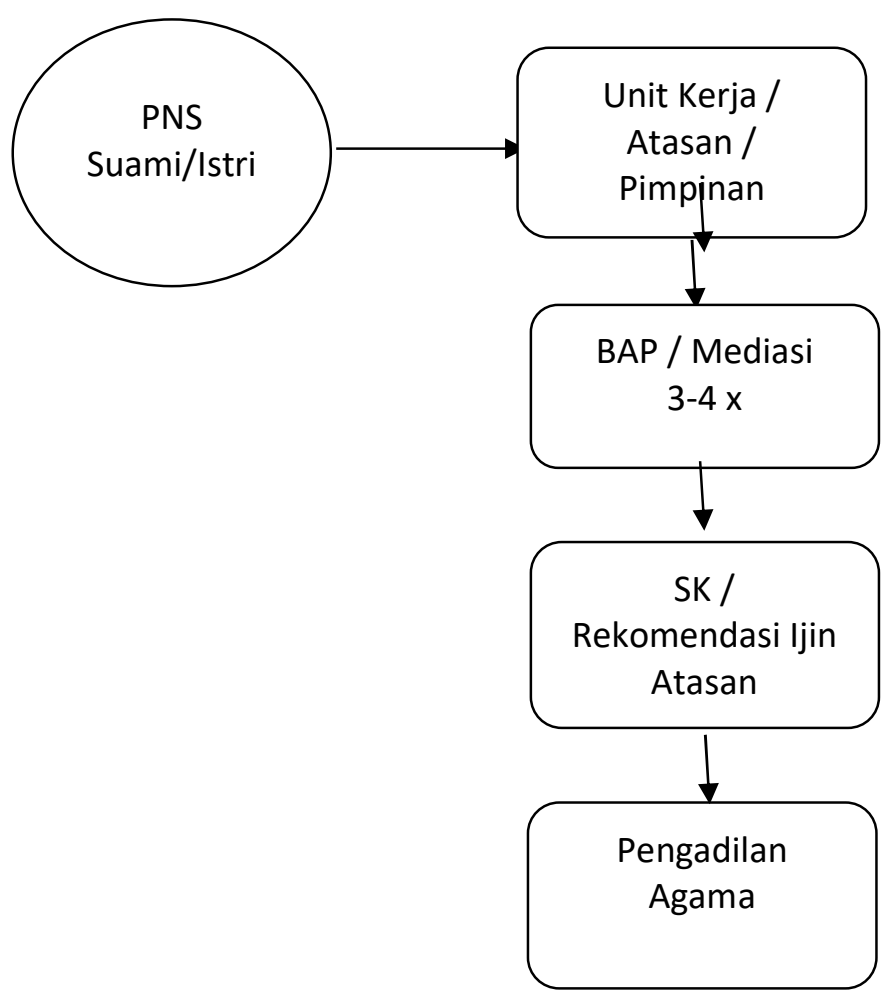

Syarat - syarat yang harus di lampirkan adalah Surat Permohonan ybs; Surat Keterangan Kepala Unit Kerja / Surat ijin; BAP Unit Kerja; Surat Keterangan Kepala Desa; Surat Pernyataan 1/3 gaji, 1/2 jika tidak punya anak; Fotokopi surat nikah; Fotokopi KTPPas Foto Suami / Istri; Fotokopi SK Terakhir.

Mekanisme Izin Perceraian bagi Pegawai Negeri Sipil diatur dalam Peraturan Pemerintah Pemerintah Nomor 45 Tahun 1990 dan Peraturan Nomor 10 Tahun 1983 tentang Izin Perkawinan dan Perceraian bagi Pegawai Negeri Sipil, artinya seorang Pegawai Negeri Sipil yang telah memiliki surat izin dari Pejabat belum dinyatakan selesai/final namun harus dilanjutkan proses izin ke tingkat Pengadilan Agama, karena surat izin yang telah dikeluarkan oleh Pejabat tidak memiliki kekuatan 
hukum yang tetap dan tidak dapat dijadikan dasar dalam proses melangsungkan perkawinan selanjutnya pasca izin perceraian dari Pejabat.

Putusan Pengadilan Agama menyangkut izin Cerai Gugat/Talak tidak selalu berdasarkan adanya izin dari Pejabat atasan langsung Pegawai Negeri Sipil yang bersangkutan, namun tidak diberikan izin oleh Pejabat atasan Pegawai Negeri Sipil tersebut Pengadilan Agama juga memiliki kewenangan untuk memutus perkara izin Cerai gugat/talak dimaksud sesuai dengan Surat Edaran Nomor : 48/SE/1990 tanggal 22 Desember 1990, Setiap pejabat harus mengambil keputusan selambatlambatnya 3 bulan terhitung mulai ia menerima surat permintaan izin tersebut.

Jika Pegawai Negeri Sipil oleh Pengadilan Agama dalam memeriksa dan memutus perkara permohonan izin Cerai setelah memberikan waktu untuk mengurus izin tersebut selama 6 bulan lebih, akan tetapi tidak mendapatkan izin dari atasan atau Pegawai Negeri Sipil tersebut tidak mengurusnya, maka Hakim Pengadilan Agama dalam memutus perkara tersebut tidak terikat oleh izin atasan Pegawai Negeri Sipil tersebut.

Sehingga pemeriksaan perkara permohonan izin Cerai dapat diteruskan pemeriksaannya termasuk dengan memberikan keputusan untuk mengabulkan atau menolak permohonan izin Cerai tersebut setelah Pegawai Negeri Sipil ditanya oleh Hakim Pengadilan Agama menyangkut izin Pejabat tersebut. Jika Pegawai Negeri Sipil menyatakan siap menerima resiko atas tidak mengurus izin atau tidak mendapat izin dari atasan tersebut, maka Hakim Pengadilan Agama akan memutus perkara dimaksud.

Artinnya izin pejabat atasan Pegawai Negeri Sipil tersebut tidak selalu menjadi standar Pengadilan Agama dalam memutus perkara permohonan izin Cerai, hanya saja Hakim Pengadilan Agama mempunyai beban moral karena yang mengajukan permohonan adalah Pegawai Negeri Sipil, karena ada kaitannya dengan sanksi hukuman Disiplin sebagai Pegawai Negeri Sipil. Maka Hakim Pengadilan Agama menganjurkan untuk mengurus sampai memperoleh izin tersebut.

Pada saat penulis membutuhkan data pendukung berupa Surat Keputusan Izin Perceraian Pegawai Negeri Sipil di Kota Mataram, tidak langsung diberikan data oleh Pegawai BKD Kota Mataram namun membutuhkan waktu sekitar tiga sampai 
empat hari, artinya dalam Manajemen Kearsipan di BKD Kota Mataram masih lemah dalam pencarian data yang diperlukan oleh penulis, karena kondisi ruang dan penataan arsip belum tertata dengan baik, padahal sarana komputer sudah cukup memadai sebenarnya sudah ada Database /Sistem Informasi Manajemen (SIM) Kepegawaian khusus Pegawai Negeri Sipil di lingkup Pemerintah Kota Mataram, namun semua bidang/bagian belum terakomodir untuk mengakses data di lingkup BKD Kota Mataram, sehingga pencarian data belum dapat berjalan sesuai harapan masyarakat yang membutuhkan.

Adapun Mekanisme Izin Perkawinan dan Perceraian harus mengacu pada Surat Edaran Nomor 48/SE/1990 tanggal 22 Desember 1990 tentang Petunjuk Pelaksanaan Peraturan Pemerintah Nomor 45 Tahun 1990 tentang perubahan atas Peraturan Pemerintah Nomor 10 tahun 1983 tentang Izin Perkawinan dan Perceraian Pegawai Negeri Sipil.

Dari data yang penulis peroleh, bahwa Pegawai Negeri Sipil di Kota Mataram yang mengajukan Izin Perceraian, terdapat sedikitnya 4 kasus perceraian tercatat di kalangan PNS di satu (1) instansi pemerintah di wilayah kota Mataram dalam kurun waktu 2010 s/d 2020. Sebelum proses izin perceraian Pegawai Negeri Sipil yang bersangkutan dipanggil oleh Tim Disiplin (bagian dari kepegawaian) untuk dilakukan tahapan mediasi. Contohnya, kasus sengketa perceraian yang dimediasi oleh tim disiplin di pemerintah kotamadya Mataram pada tahun 2010. Tim Mediasi tersebut terdiri daru unsur-unsur Pejabat di lingkungan Sekretariat Kota Mataram, unsur inspektorat, unsur Bagian Hukum Setda Kota Mataram dan pihak Kementerian Agama Kota Mataram. Tujuan mediasi adalah untuk merukunkan kembali Pegawai Negeri Sipil dengan pihak istri/suami yang bermasalah agar dapat kembali hidup rukun, damai dan sejahtera sesuai dengan tujuan rumah tangga, sebelum permasalahan dilanjutkan ke tingkat Pengadilan Agama.

Setelah melalui proses mediasi oleh Tim Disiplin Setda Pemerintah Kota Mataram namun belum berhasil, maka langkah berikutnya adalah proses pemberian izin perceraian oleh Pejabat yang berwenang, dengan mempelajari berkas yang diajukan pihak Pegawai Negeri Sipil yang bersangkutan. Apabila berkas tersebut ternyata belum sesuai dengan aturan di bidang kepegawaian maka pihak terkait 
segera melengkapi data sesuai yang ditentukan. Dari data izin perceraian yang kaini peroleh, belum pernah pihak BKD menolak permohonan izin tersebut, artinya pihak BKD telah melakukan langkah-langkah pembinaan dan mediasi sesuai aturan, baru proses final berupa surat keputusan izin perceraian bagi Pegawai Negeri Sipil oleh pejabat yang berwenang yaitu Sekretaris Daerah atas nama Walikota Mataram.

Dari wawancara penulis dengan Saudara Marwi staf pada Badan Kepegawaian Daerah (BKD) Kota Mataram tanggal 27 Agustus 2010 menyatakan, pernah ada Pegawai Negeri Sipil yang mengajukan izin perceraian akhirnya menangguhkan usul dimaksud, karena timbul kesadaran dan penyesalan setelah melihat kondisi anak-anak yang tidak terurus. Artinya Tim Disiplin di lingkungan Kota Mataram telah berusaha untuk memberikan bantuan melalui mediasi, dan memberikan motivasi agar para Pegawai Negeri Sipil yang memiliki permasalahan keluarga dapat diselesaikan dengan jalan arbitrase/mediasi.

D. Peranan Mediasi Badan Penasehatan Pembinaan dan Pelestarian Perkawinan (BP4)

Sebelum proses izin perceraian Pegawai Negeri Sipil ke atasan yang berwenang mengeluarkan surat keputusan izin dimaksud, masih ada celah dan upaya penyelesian permasalahan keluarga melalui Badan Penasehat Perkawinan dan Penyelesaian Perceraian (BP4) dalam hal terjadinya gugatan perceraian, seperti yang terdapat pada Pasal 76 ayat (2), adalah sebagai penengah untuk mengupayakan rekonsiliasi diantara suami istri, jika memang hal itu diperlukan Pengadilan. Hal itu diatur pada Pasal 31 ayat (2) Penjelasan Peraturan Pemerintah Nomor 9 Tahun 1975 tentang Pelaksanaan Undang-Undang Nomor 1 tahun 1974 tentang Perkawinan.

Upaya mediasi / islah seorang Pegawai Negeri Sipil yang sedang dalam proses perceraian, dapat melalui lembaga BP4 (Badan Penasehat Perkawinan dan Penyelesaian Perceraian) yang kewenangannya dilakukan oleh Kantor Urusan Agama Kecamatan sebagai tempat pencatatan nikah, dimana Pegawai Negeri Sipil yang bersangkutan tinggal. Dari jumlah 6 Kecamatan yang ada di Kota Mataram, namun yang meiniliki Kantor Urusan Agama (KUA) baru 3 Kecamatan yaitu Kantor 
Urusan Agama Kecamatan Mataram, Ampenan dan Cakranegara, karena Kecamatan lain adalah masih relatif baru dibentuk pasca pemekaran wilayah. ${ }^{23}$ Tujuan mediasi adalah untuk merukunkan kembali Pegawai Negeri Sipil dengan pihak istri/suami yang bermasalah agar dapat kembali hidup rukun, damai dan sejahtera sesuai dengan tujuan rumah tangga, sebelum permasalahan dilanjutkan ke tingkat Pengadilan Agama.

Dari data jumlah Pegawai Negeri Sipil yang pernah konsultasi perihal permasalahan sengketa perkawinan/perceraian tercatat sedikitnya 30 mediasi oleh BP4 KUA di wilayah kota Mataram terhadap sengketa perceraian di kalangan PNS dalam kurun waktu 2010 s/d 2020.

Hasil wawancara penulis dengan Saudara Zakaria, S.Ag. sebagai penanggung jawab dalam bidang pembinaan perkawinan Kantor Urusan Agama Kecamatan Ampenan, menunjukkan bahwa dalam setiap tahun ada Pegawai Negeri Sipil yang datang untuk konsultasi dalam rangka upaya penyelesaian sengketa perceraian. Data jumlah Pegawai Negeri Sipil yang pernah konsultasi perihal permasalahan perceraian di KUA kecamatan Ampenan terdata minimal 1 sampai dengan 4 keluarga yang termediasi dalam tiap tahunnya sejak tahun 2010 sampai dengan 2020.

Dari jumlah Pegawai Negeri Sipil yang mempunyai masalah Perkawinan/Perceraian kadang yang datang konsultasi ke pihak BP4 hanya pihak suami/istri, namun dalam rangka upaya penyelesaian sebelum melalui proses Pengadilan Agama, upaya pencegahan yang dilakukan oleh Kantor Urusan Agama Kecamatan berusaha untuk mendamaikan dari pihak Pegawai Negeri Sipil yang memiliki sengketa perkawinan. Dari data jumlah Pegawai Negeri Sipil yang mempunyai permasalahan perkawinan menurut Pegawai Pencatat Nikah Kecamatan Mataram, Cakranegara dan Ampenan alasan perselisihan dan pertengkaran antara suami/istri secara terus menerus dan tidak ada harapan lagi untuk hidup rukun dalam rumah tangganya, sebagaimana tersebut dalam Pasal 19 Peraturan Pemerintah Nomor 9 Tahun 1975 tentang Pelaksanaan Undang-Undang

${ }^{23}$ Pemerintah Daerah Kota Mataram, Perda Kota Mataram Nomor 5 Tahun 2008 Tanggal 25 Juni 2008 Tentang Pembentukan Susunan Organisasi Perangkat Daerah Kota Mataram (Mataram, 2008). 
Perkawinan, alasan ekonomi keluarga dan karena alasan perselingkuhan. Bahkan di dalam pengamatan terakhir penulis sendiri terhadap fenomena perceraian di keluarga PNS, tidak sedikit yang disebabkan oleh pengaruh buruk yang diakibatkan oleh kurangnya kesadaran akan sikap bijak dalam bermedia sosial lewat aplikasi WA, Instagram, Facebook dan aplikasi lainnya yang mudah dioperasikan dalam gagdet dan tablet.

Begitu juga yang terjadi di Pemerintah Kota Surabaya telah memblokir Facebook, sebab situs jejaring sosial itu mengakibatkan sejumlah Pegawai Negeri Sipil di Pemerintah Kota Surabaya bercerai dan berselingkuh. Ada beberapa surat masuk dari Pegawai Negeri Sipil yang menyatakan bahwa istri atau suaminya bercerai atau selingkuh setelah aktif di Facebook, kata Kepala BKD Pemerintah Kota Surabaya, Yayuk Eko Agustin. Mengapa fenomena perselingkuhan dan perceraian akibat penggunaan Facebook ini kemudian menimpa Komunitas Pegawai Negeri Sipil, apa karena Facebook di kantor gratis, atau lingkungan kerja yang semakin membuka peluang terjadinya perselingkuhan dan perceraian. ${ }^{24}$

Antropolog Universitas Padjadjaran, Budi Rajab, menilai lingkungan kerja Pegawai Negeri Sipil merupakan daerah nyaman. Banyak orang yang menginginkan jadi Pegawai Negeri Sipil karena ingin nyaman bekerja. Dengan gaji tetap dan jaininan hari tua yang pasti membuat Pegawai Negeri Sipil bekerja lebih santai. Lingkungan nyaman inilah yang kemudian memunculkan perilaku-perilaku menyimpang. Perselingkuhan dan perbuatan-perbuatan melanggar norma-norma sangat berpotensi terjadi. Menurut Budi Rajab, keadaan ini diperparah dengan budaya perinisif yang makin berkembang di masyarakat. Sehingga muncullah masalah-masalah dalam rumah tangga akibat perselingkuhan, perceraian pun tidak terhindarkan. ${ }^{25}$

Memelihara komunikasi yang baik dan sehat dalam kehidupan perkawinan, suatu keluarga akan bahagia manakala didalam keluarga tersebut para anggotanya setiap saat dapat melakukan komunikasi atau berkomunikasi satu sama lain, tanpa

24 "Http:/ /Sanasinihepi.Blogspot.Com."

25 "Http:/ /Www.Indonesia-Monitor.Com," last modified 2010, accessed June 11, 2010, http:/ / www.indonesia-monitor.com. 
hambatan, penghalang, tanpa tembok peinisah diantara mereka. Setiap saat tersedia waktu yang selalu dapat digunakan untuk berkomunikasi, dan terbuka bagi yang lain. Komunikasi yang baik akan tercipta manakala kebutuhan pihak lain untuk didengarkan oleh pasangan dapat benar-benar dilaksnakan. Untuk mencapai itu maka yang paling utama adalah adanya pengertian. Dari pengertian tersebut harus dapat mewujudkan suatu tindakan dimana pasangannya benar-benar melaksanakan sebagai hasil dari komunikasi yang telah dilakukan. ${ }^{26}$

\section{E. Penutup}

Mekanisme izin dan fungsi mediasi sengketa perceraian bagi Pegawai Negeri Sipil di kota Mataram dalam kurun waktu 2010 sampai dengan 2020 telah diatur dalam beberapa ketentuan antara lain Pasal 39 Undang-Undang Nomor 1 Tahun 1974 tentang Perkawinan, Pasal 19 Peraturan Pemerintah Nomor 9 Tahun 1975 tentang Pelaksnaan Undang-Undang Nomor 1 Tahun 1974 tentang Perkawinan dan Kompilasi Hukum Islam dan berjalan seoptimal mungkin. Dalam 10 tahun terakhir tersebut, terdata minimal 1 sampai dengan 5 sengketa perceraian yang dimediasi oleh BP4 di KUA setiap kecamatan di Kotamadya Mataram.

Alasan dan faktor yang paling potensial menyebabkan pegawai negeri sipil cenderung untuk melanggar disiplin PNS dalam hal ini timbulnya sengketa perceraian adalah karena izin atasan/pejabat yang berwenang masih dianggap tidak penting sehingga oleh karenanya bersifat administratif saja. Selain itu, bahwa terjadinya sengketa perceraian di kalangan PNS karena faktor terhambatnya komunikasi yang harmonis dalam kehidupan keluarga dan pengaruh buruk dari kurangnya kesadaran dalam bersikap bijak bermedia sosial. Hubungan di ruang maya ini sepertinya kurang bisa dikendalikan dan diawasi secara langsung karena pengoperasiannya sangat familiar (user friendly).

\section{Daftar Pustaka}

Bapek, Sekretariat. Izin Perkawinan Dan Perceraian PNS, Peraturan Kepegawaian Yang

26 “Http:/ /Www.Bkdiklat.Cirebonkota.Go.Id," last modified 2010, accessed June 9, 2010, http://www.bkdiklat.cirebonkota.go.id. 
Berkaitan Dengan Banding Adininistrtratif Ke BAPEK, 2007.

Departemen Agama RI. Al-Qur'an Dan Terjemahan. Jakarta: Pustaka Amani, 2006.

Direktorat Pembinaan Badan Peradilan Agama, Direktorat Jenderal Pembinaan

Kelembagaan Agama Islam. Kompilasi Hukum Islam, n.d.

Idris, Ramulyo. Hukum Perkawinan Islam Suatu Analisis Dari Undang-Undang Nomor 1

Tahun 1974 Dan Kompilasi Hukum Islam. Jakarta: Bumi Aksara, 2005.

Idrus, Muhammad. “Arbitrase Perkawinan Di Indonesia Dan Pakistan (Sebuah Studi

Komparatif)." IAIN Sunan Kalijaga, 2003.

Indroharto. Usaha Memahami Undang-Undang Tetang TUN. Jakarta: Pustaka Sinar Harapan, 2000.

M. Hadjon, Philipus. Penataran Hukum Administrasi. Surabaya, 1988.

- - Pengantar Hukum Administrasi Indonesia. Yogyakarta: Gadjah Mada

University Press, 1990.

- - - Pengantar Hukum Perizinan. Surabaya: Yuridika, 1993.

Mataram, Pemerintah Daerah Kota. Perda Kota Mataram Nomor 5 Tahun 2008 Tanggal

25 Juni 2008 Tentang Pembentukan Susunan Organisasi Perangkat Daerah Kota Mataram. Mataram, 2008.

Mustafa, Bachsan. Pokok-Pokok Hukum Adininistrasi Negara. Bandung: Alumni, 1985.

Raharjdo, Satjipto. Hukum Dan Masyarakat. Bandung: Angkasa, 1980.

Salam, Moch. Faisal. Penyelesaian Sengketa PNS Di Indonesia Menurut Undang-Undang No. 43 Tahun 1999. Bandung: Mandar Maju, 2003.

Saleh, Abdurrahman, and Ridwan Sahrani. Masalah Hukum Islam Di Indonesia. Bandung: Alumni, 1978.

Soekanto, Soerjono. Pengantar Penelitian Hukum. Jakarta: UI Press, 1985.

- - - . Pokok-Pokok Sosiologi Hukum. Jakarta: PT. Raja Grafindo Persada, 1988.

Sulaeman, Rasyid. Fiqih Islam. Bandung: Sinar Baru Algesindo, 2003.

Supriadi, Wila Chandra. , Hukum Perkawinan Indonesia Dan Belanda: Suatu Penelitian

Sejarah Hukum Perbandingan Tentang Hukum Perkawinan Indonesia Dan Belanda Dalam Periode Tahun 1945 Sampai Sekarang. Bandung: Mandar Maju, 2002.

Toha, Miftah. Birokrasi Dan Politik Di Indonesia. Jakarta: PT. Raja Grafindo Persada, 2002. 
Wahab, Abdul. Analisis Kebijakan Dari Formulasi Ke Implementasi Kebijakan Negara. Jakarta: Bumi Aksara, 1997.

“Http:/ /Sanasinihepi.Blogspot.Com."

“Http://Www.Bkdiklat.Cirebonkota.Go.Id." Last modified 2010. Accessed June 9, 2010. http:/ / www.bkdiklat.cirebonkota.go.id.

“Http://Www.Indonesia-Monitor.Com.” Last modified 2010. Accessed June 11, 2010. http:/ / www.indonesia-monitor.com. 